\title{
Ramona Coman
}

\section{MECHANISMS OF EUROPEANISATION AND COMPLIANCE IN JUDICIAL POLITICS: UNDERSTANDING THE PAST AND ANTICIPATING THE FUTURE}

DOI: $10.1515 /$ ppsr-2015-0005

\begin{abstract}
Recent developments in Hungarian constitutional and judicial politics have given impetus to question not only the outcomes of democratisation and Europeanisation, but also the efficacy of the European Union's compliance mechanisms. In 2010, Hungary, one of the forerunners in building democracy made the headlines with Fidesz's attempts at adopting a new Constitution and implementing cardinal laws along with controversial institutional, cultural, religious, moral and socio-economic policies. This article attempts to depict the transformative power of the European Union within a sensitive policy area which touches upon States' pouvoris régaliens: the independence of the judiciary.
\end{abstract}

Keywords: Hungary, judicial reform, judicial politics, Europeanisation, conditionality, independence of the judiciary

\section{Introduction}

Recent developments in Hungarian constitutional and judicial politics provide a case to question the outcomes of democratisation and Europeanisation in Central and Eastern Europe through the stability of the democratic framework in its constitutional, behavioural and attitudinal dimensions (Spinner 2005, p. 444). Starting in 2010, Hungary, one of the forerunners in building democracy and installing a market economy before its accession to the European Union (EU) made the headlines with Fidesz's attempts at adopting a new constitution and implementing cardinal laws along with controversial institutional, cultural, religious, moral and socio-economic policies. The inclusion of vague and general provisions in the constitution gave rise to a significant degree of uncertainty and the planned reforms risked reviving the "ghosts" from the beginning of the transition process such as past greatness, homophobia, and nationalism. Critics saw the measures promoted by Fidesz as dangerous deviations from democratic norms and EU treaties. In fact, at European level, several MEPs and officials argued that "no accession country would be allowed to join the EU if the situation was similar to the one in Hungary" (Renate Weber, parliamentary debates, January 2012). The attempts at imposing governmental control over institutions whose independence is protected by EU treaties and the empowerment of political institutions at the expense of the judiciary have been considered by many as threats to democracy and to EU democratic values. 
In 1993, the Copenhagen criteria was set up in order to avoid instability, authoritarianism or economic collapse within the Union and, to reassure the old Member States that the new ones will not be politically unstable and economically burdensome to the Union (Grabbe 2002, p. 249). The EU accession opened a window of opportunity for undertaking democratic reforms and to consolidate the administrative and judicial capacity of the new Member States. However, recent debates at EU level have brought two related questions to the surface: To what extent has the EU been decisive in reshaping judicial institutions in the former communist States prior to accession? Is the power of the EU great enough to ensure the respect of democratic principles under the authority of the article 7(3) in the Treaty of the EU, which allows it to act preventively if there is a clear threat of a breach of the common values? When does the EU affect the transformation of domestic institutions in the former communist countries?

By taking the example of the independence of the judiciary, this article will show that the mechanisms of Europeanisation, such as conditionality, explain the timing of reforms, yet have little explanatory power when it comes to understanding the institutional models of judicial governance established in the new Member States of the EU and, the degree of independence granted to the judicial councils. The European Union has been successful as a leader in opening up a critical juncture for democratic reforms (O'Dwyer 2006, p. 222) and in maintaining the principle of the independence of the judiciary on the political agenda (Coman 2009). However, the Copenhagen criteria and the Commission's progress reports had very mixed results (Priban 2010, p. 16). By exploring the interactions between domestic and European actors, scholars of judicial reforms have tried to capture the ability of the Union to reshape politics, policies and polities in the region. Europeanisation studies have demonstrated how greatly the effects of this process can differ across policy sectors as well as across countries. It appears that the mechanisms of Europeanisation did not bring major alterations to the existing institutional frameworks in Poland, the Czech Republic and Hungary (Uitz 2010, p. 47; see also Seiber-Fohr 2011). Although the EU offered an "important legitimising force for 'selling' these reforms to the CEECs' electorate" (Papadimitriou and Phinemore, 2004, p. 622), the choice of tools and institutional models through which the broad Copenhagen criteria were to be achieved remained essentially in the hands of domestic political elites. Thus, the effect of the conditionality appeared to be entirely dependent on national factors.

By addressing these questions, the article is an attempt to better understand the transformative power of the EU in judicial politics. It argues that the EU's mechanisms of Europeanisation concerning judicial reforms: such as conditionality, monitoring, benchmarking, advice and twinning share two characteristics: diversity and contestability.

This article is organised as follows: Firstly, it exposes the aims and the outcomes of judicial reforms in Central and Eastern Europe by looking at Romanian, Bulgarian, Polish, Hungarian and Czech challenges and experiences. Focused on the establishment and the reform of judicial councils in the region, it illustrates variation in terms of institutional models. Secondly, the article explains this variation by looking at the transformative power of the EU. 


\section{Judicial reforms in Central and Eastern Europe}

Since the collapse of communism, judicial institutions in Central and Eastern Europe have witnessed an increasing number of reforms (Coman and De Waele 2007; Coman 2009; Dallara 2007; Dallara 2008; Piana 2010, Seiber-Fohr 2011; Hammerslev 2011). At the beginning of the 1990s, constitutional revisions led to a sanctioning of the separation of power. Later, in the accession context, judicial reforms became the sine qua non condition of accession (Coman 2009; Piana 2010), as essential ingredients not only for the functioning of the internal market but also for the establishment of a European space of freedom and security. Because of the subordination of the judiciary to the communist parties prior to 1989, the enlargement policy developed by the European Commission devoted particular attention to the improvement of the judicial and administrative capacity of the new Member States. The independence of the judiciary (Larkins 1996): which is an international norm received ample attention within the community of rule of law promoters. Through its Regular Reports, the European Commission identified a number of dysfunctions and a series of goals to be reached. The aim was to curb instances of politicisation and the practices inherited from the communist regimes. This was done by reducing the institutional prerogatives of the executive over the judiciary (Magalhaes 1999; Fleck 2011: 795). Fundamentally, the European Commission recommended that the independence of the judiciary should be real, and free of inference from other branches of power. The Commission stressed this through the efficient training and appointment of judges, work of self-governing bodies and the overall work of the courts (Kochenov 2004, p. 21). Indirectly, the European Commission recommended the establishment of judicial councils, institutions designed in several Western democracies after the Second World War "to maintain an appropriate balance between judicial independence and accountability" (Ginsburg and Garupa 2009, p. 201).

At the beginning of the 1990s, one priority common amongst all of the new governments established in Central and Eastern Europe was to adopt new laws on judicial organisation aimed at consolidating the independence of the judiciary. Concretely, the mechanisms by which independence is achieved are above all institutional (Domingo 1999: 154). However, the implementation of this principle generally poses a variety of dilemmas to policy makers, both at domestic and at international level. The creation of judicial councils challenges domestic structures of power. It implies a transfer of power from the national ministries of justice to judicial councils. How much independence should judicial councils be afforded? This issue gave rise to vivid debates not only in the former communist countries but also at international level.

After the collapse of communism, by creating judicial councils, most of the new Member States of the EU turned towards a model of self-administration of the judiciary. Each country followed a different path to reform with a different institutional outcome. The first judicial councils were created in Romania (in 1909) and Bulgaria (in 1910) at the beginning of the $20^{\text {th }}$ century (Melone 1996, p. 234) in order to act as consultative bodies to the Ministries of Justice on personnel policy (Melone 1996, p. 234). They re-emerged in the context of the transition to democracy. 
In the post-communist context, the power of the Bulgarian Supreme Judicial Council had been significantly extended. The Bulgarian constitution, adopted in 1991, established a 'powerful Supreme Judicial Council (SJC) in charge of promoting, assigning and dismissing magistrates' (Magalhaes 1999, p. 50). The Council determines the number of judges and prosecutors, organises and conducts the competitions for the positions of judge and prosecutor, appoints, promotes, transfers and discharges judges. According to Schonfelder, 'anyone who reads the sections of the Bulgarian constitution with regards to the judiciary as well as the judiciary act of 1994 is bound to be impressed by the accumulation of institutional safeguards protecting the judicial system' (2005, p. 62). Accordingly, the role of the Ministry of Justice has been formally reduced in judicial governance. The Minister of Justice has the right to serve as the chair of the meetings of the SJC, but without voting privileges (Melone 1996, p. 234).

By contrast, in Romania after the collapse of communism the establishment of the Superior Council of Magistracy was delayed for several years (interview, judge CSM, Bucharest, April 2005). From the beginning of the 1990s until 2003 the institution was nothing more than an empty structure, without any power and visibility in the administration of the judiciary. The Constitution provided legal grounds for the empowerment of the Superior Council of Magistracy (CSM). However, the legislation passed in 1992 contained many ambiguities regarding the competences of the Ministry of Justice and of the CSM. The establishment of the Council was delayed for several years and its members met only twice a year in the buildings of the Ministry of Justice (interview, judge CSM, Bucharest, April 2005). The prerogatives of the institution were clarified in 2004, when the independence of the judiciary represented one of the most salient topics in domestic political debates (Coman 2009).

In Poland, the National Council of the Judiciary was established in the context of the round-table negotiations. The competences of the council were extended in 1997, 2001 and 2003, but without reducing the roles of the Ministry of Justice in judicial politics. In 2011, a new regulation specified the scope and the activities of this institution. The Czech Republic remained the 'black sheep' (Bobek 2007) because of its resistance to create this type of institution. Although the European Commission encouraged its creation, this option did not find any overwhelming support at domestic level. Here, the traditional model of state administration of the judiciary and the role of the Ministry of justice has been maintained over time because 'politicians did not consent to the transfer of such broad powers to the judiciary' (Kosar 2010, p. 17).

In 1997, through the empowerment of the National Judicial Council, Hungary witnessed the most radical change in judicial independence (Bobek 2007; Fleck 2011). Pedro Magalhaes examined the outcomes of judicial reforms from 1989 to 1997 and showed that at the beginning of the transition process, the amended Hungarian constitution "remained salient about the supervision of judicial personnel" $(1999, \mathrm{p}$. 53). The former communist powers of the executive over the judiciary "were fundamentally untouched by the transition" (Magalhes 1999, p. 55) allowing the Ministry of justice to retain its relatively unfettered administrative and disciplinary powers" (1999, p. 53). Starting in 1997, the Hungarian Minister of Justice, Pal Vastagh, a founding member of the Hungarian 
Socialist Party, presented judicial independence as a government priority. By advocating the creation of the National Judicial Council, Vastagh's aim was to reduce the powers of the executive over the judiciary and to consolidate the guarantees of independence of judicial institutions. A comprehensive reform of the judiciary took place with the passing of the Act on the Organisation and Administration of Courts and the Act on the Legal Status and Remuneration of Judges (OSI 2001, p. 195). On this basis, the National Council of Justice was established with the aim of proposing legislation and giving advice on laws related to the judiciary. Composed by a majority of judges ${ }^{1}$, this new institution was designed to oversee the promotion, appointment and evaluation of judges. The European Commission appreciated the Hungarian "seriousness" in preparation for membership (European Commission 1999, p. 58) and the efforts undertaken to address the weaknesses of the judiciary (European Commission 1998, p. 8).

In recent years, the independence of the judiciary is subject to new challenges. Domestic actors deplore the increasing dissatisfaction with the functioning of the model of selfadministration of the judiciary (Schonfelder 2005: 61; Fleck 2011). The empowerment of the judicial councils gave rise to mitigated results and opinions. Several surveys showed that judges were still perceived as 'unreliable, inefficient and corrupt' (Schonfelder 2005: 61). Experts argued that the radical reforms undertaken in Hungary, Poland, Romania and Bulgaria moved power and undue influence from one bureaucratic institution (the Ministry of Justice) to another (the judicial councils) (Bobek 2007, p.112; Parau, 2011). In Romania, it appears that the Council "no longer perform(ed) its mandate as the representative of judges but rather as someone who own(ed) the judiciary, made the rules for the judiciary and ruled the judiciary" (Parau 2011: 647). While Romania and Bulgaria continued to follow the benchmarks of the mechanism of cooperation and verification (MCV) of the EU, Poland, Hungary and the Czech Republic witnessed new tensions between judicial and political actors.

In Poland (from 2005 to 2007) and in Hungary (since 2010) political actors have tried to reduce the powers of the recently empowered judicial councils. ${ }^{2}$ Critics saw the measures promoted by Law and Justice in Poland in 2005 and by Fidesz in Hungary as a deviation from democratic norms and EU treaties. In Poland, from 2005 to 2007 , the relationship between the executive and the judiciary was tense. During his term, President Kaczynski never missed a chance to express his hostility towards judges (Bodnar \& Bojarski, p. 729) and started organising a coalition to amend the Constitution. According to a series of international associations, the aim of the executive was to empower the Ministry 'to appoint temporary presidents, to create vacancies and nominate judges for those vacancies, thereby reducing the role of the NCJ in those appointments and giving the Minister of Justice greater influence over the composition

${ }^{1}$ It gathered together 15 members, including 4 ex official members (the Minister of Justice, the Prosecutor General, the President of the National Bar Association and the President of the Supreme Court), two members of Parliament and nine judges (elected by delegates chosen by all ordinary courts in the country). The nine elected judges and the President of the Council (who acts also as President of the Supreme Court) constituted a two-third majority in the Council (OSI 2001, p. 199).

2 No concrete policy plans to reform them have materialised in Romania and Bulgaria. 
of the judiciary' (International Bar Association 2007, p. 24).Regardless, the prerogatives of the NCJ remained unchanged.

However, in Hungary, in recent years it has been argued that the 1997 Hungarian reform: which led to the consolidation of the National Judicial Council "contained several dangers" such as a "lack of efficiency, decline of trust in the judiciary, corruption and ideological bias" (Fleck 2011: 797). In December 2011 the Hungarian Parliament passed new laws on the organisation of the courts. The main rationale behind these measures was to reform the National Judicial Council. According to a series of representatives of the government led by Prime Minister Orban, the rationale behind the recent reform lies in the fact that "the decisions of the NCJ were influenced by particular interests". Accordingly, in 2011 a new institution, the National Judicial Office $(\mathrm{OBH})$, was created in order to fix some deficiencies in the functioning of the former NCJ and to "restore the faith of Hungarian citizens in the administration of justice" (Hungarian Government June 2012). This led the Hungarian executive to empower the president of the new National Judicial Office, who is elected for a nine-year term. As Bankuti, Halmai and Scheppele recently pointed out, "the ordinary judiciary has lost a great deal of its independence" (2012, p. 143). According to the European Commission, under the new institutional framework, "one person alone now makes all important decisions on the judiciary, including the appointment of judges". The president of the National Judicial Office also has the power to "reassign specific cases from the courts where they are assigned by law to any other court in the country" (Bankuti, Halmai and Scheppele 2012, p. 143). Another area of contention lies in the retirement of 274 judges and the premature termination of the mandate of the former president of the Supreme Court in 2011, who was elected for six years in June 2009. According to specialists in constitutional and judicial politics, applying the general retirement age to judges is questionable due to the core principles and rules pertaining to the independence and immovability of judges (Council of Europe, Opinion no.621/2011, p. 10).

These provisions surfaced debates both at domestic and at EU level. A variety of actors claimed the country was sliding towards authoritarianism through undemocratic reforms and tried to persuade international actors that the independence of the judiciary had been undermined. The Hungarian government tried to constrain the role of the EU in this field. Initially, the Hungarian Prime Minister, Viktor Orban, strongly rejected any form of external influence arguing that "no European Prime Minister, no European government is in a position to tell Hungarians what kind of constitution they can have and what not" (European Parliament, 5 July 2011). By opposing European and international judgements, he stressed that "calling into question the commitment of the Hungarian people and the Hungarian Government to democracy is an insult to the Hungarian people" (European Parliamentary debates, January 2011). Progressively, Orban and the members of the Hungarian executive softened the tone of their declarations in order to persuade the international actors that they would take "fast and effective measures to assuage concerns over domestic policy” (The Budapest Times, 21 March 2012). 


\section{The Transformative Power of the Union}

The enlargement policy did not bring major alterations to the domestic institutional frameworks in Hungary (Uitz 2010, p. 47), the Czech Republic (Sticka 2007, p. 199) or Poland (see Seiber-Fohr 2011). Paradoxically, the power of the EU was greater in Romania where the empowerment of the Superior Council of Magistracy conditioned the outcomes of accession negotiations (Coman 2009). Prior to accession, domestic reformers drew inspiration from the old Member States and from a series of international organisations such as the Council of Europe (Coman 2009; Piana 2010), not from the EU per se. In spite of the active role played by the European Commission and the regular evaluation of the progress made by the candidate countries in what concerns the independence of the judiciary, the choice of tools and institutional models through which the conditions are to be achieved remained very much in the hands of domestic political elites.

It is common to explain the differential impact of the Union by emphasising the ability of domestic actors to oppose EU conditions, as well as the lack of commitment of political elites to EU integration. It has been demonstrated that, by resisting or supporting Europe, social and political actors define and constrain the role of the EU in domestic politics and policies (Radaelli and Exadaktylos 2012; Woll and Jacquot 2004). However, while there are cases that clearly show that under-compliance is a deliberate choice of domestic actors or due to structural legacies, this article claims that the power of the EU and more specifically the effects of Europeanisation mechanisms have been overestimated.

As demonstrated in the previous section, recent developments in judicial and constitutional politics in Hungary have raised important questions at European level about the instruments and legal grounds on which the Union and the European Commission base their action. The Hungarian case revealed that policy-makers and

high level officials are confronted with major dilemmas such as: How to find a middle way between effective and legitimate instruments of compliance? How to maximise the impact of the EU and minimise inconsistency? How to conciliate diversity and flexibility regarding rule of law promotion?

This article claims that what is to be explained is the transformative power of the EU and its mechanisms of Europeanisation and compliance. Accordingly, the originality of this article lies in its angle of analysis: instead of explaining change and inertia at domestic level resulting from the impact of the EU on Member States, it examines change and inertia in the realm of the mechanisms of compliance and instruments of public policy. This approach has major methodological implications which strengthen the originality of this article. Firstly, the European dimension: explored here in terms of Europeanisation, changes its status from an independent variable (i.e. something which explains) to a dependent variable (i.e. something to be explained). Secondly, taking mechanisms and instruments of public policy seriously is not only a methodological question, but also a puzzle for empirical research.

Each European public policy has its own instruments and mechanisms of compliance (IPMC). They include norms, incentives, rhetoric, rules, tools, finances, sanctions and so on (Grabbe 2002; Papadimitriou and Phinnemore 2004; Hill and Knill 2006; Ravinet 
2011). Analysing them reveals not only the complexity of the EU's mission, but also the ambiguities of its roles and the sources of tension and conflict between States and EU institutions. They can be differentiated among many lines (Kotzian, Knodts and Urdze 2011, p. 999): there are "strong" and "weak" instruments, instruments that "respect sovereignty" and "intrusive instruments", as well as binding and non-binding rules (Saurugger 2012, p. 112). IPMC matter: it is a combination of mechanisms, rather than a single policy, that enables the Union to be effective in reshaping domestic public policies and realities. Today, these IPMC deserve more political and scholarly attention. They are indicators of the ability of the EU to promote change, to increase compliance and, to prevent instances of under compliance at domestic level. Below, the article examines the origins and evolution of the EU's mechanisms of Europeanisation and compliance related to judicial reforms in the new Member States of the EU.

\section{Soft mechanisms of Europeanisation}

In the mid-1990s, studying the post-communist transformation in terms of Europeanisation became not only fashionable but also a prêt à porter conceptualisation in comparative politics and EU studies. The concept enjoyed great popularity among scholars examining policy change in domestic arenas, both in the old and new Member States of the EU. In several fields of study and disciplines the EU was not only an important variable to consider but also a matter of normative (Ladrech 2010) and, more recently, methodological concern (Radaelli and Exadaktylos 2012). The former candidate countries represented a promising empirical field to test the hypotheses of Europeanisation for several reasons. Firstly, the adoption of EU rules implied "the most massive international rule transfer in recent history" (Schimmelfennig and Sedelmeier 2004). Secondly, the external incentives set by the EU were reinforced by the asymmetry of power between the EU and the CEECs (Juncos 2011, p. 372). Thirdly, applying the Europeanisation conceptual framework to the former communist countries strengthened the assumption that "the degree of adaptational pressure generated by Europeanisation depends on the "fit" and "misfit" between European institutions and domestic structures" (Risse, Green Cowles and Caporaso 2001). In this respect, Brusis (2005, p. 24) argued that "the lack of consolidated institutions may facilitate the incorporation of EU rules because the given formal institutional arrangements are not embedded in a social and cultural infrastructure and are therefore more amenable to institutional engineering". Hence, several authors pointed out that the polities and policies of the new Member States have been affected by the EU accession process and that "the impact of the EU on domestic politics and institutions of the post-communist states has been profound" (Ladrech 2010, p. 109). In order to demonstrate how the EU changes domestic institutions, conditionality, benchmarking and monitoring, advice, twinning and technical assistance received ample attention in the literature (Grabbe 2001).

The EU conditionality set in Copenhagen appeared to be the main mechanism explaining adaptation and compliance (Grabbe 2001; Pridham 2006). Scholars emphasised that conditionality proved to be effective when the EU coerced the countries reluctant to comply with the threat of exclusion and postponing accession. Gate-keeping remained 
the main mechanism through which the EU clearly sanctioned non compliance to its standards and rules. Slovakia under Meciar is the most quoted example in demonstrating the impact of the EU's conditionality and transformative power (Haughton 2007; Sadurski 2008). The decision to postpone the accession date of Bulgaria and Romania or the menace of cutting financial support is also illustrative of this assumption. The European Commission sanctioned inertia and rather rewarded any form of absorption and accommodation of European norms and acquis communautaire. However, recent works have promoted a more cautious approach with regards to the transformative power of the EU in the former communist countries (Hughes, Sasse and Gordon, 2004b; Phinnemore and Papadimitriou, 2004; Epstein, 2005; Haughton, 2007; Coman, 2009).

What follows shows that conditionality explains the timing and the integration of the European dimension in domestic politics, but has little explanatory power when it comes to understanding the degree of independence and the institutional models of judicial governance.

There is a shared consensus that the political conditionality to which the new Member States have to converge is vague and does not define what constitutes a stable democracy (Grabbe 2002, p. 253; Pridham, 2006). Prior to accession, observers of the enlargement process and political elites from Central and Eastern Europe complained about the ambiguity regarding when criteria have been met and what rule of law the Union requires the candidate countries to adhere to (Kochenov 2004, p. 1). Despite the attempts to depoliticise these criteria through a variety of indicators, the process in itself remained a political one. The separation of powers, judicial review, and check and balances are general guiding principles in European political regimes, yet they can take very different forms (Wolczuk 2007, p. 229). There is no a uniform matrix of institutional design in Europe with regards to their implementation. In any field related to political criteria and democratisation, the common feature of the EU's conditionality is the lack of models around which to converge. The Copenhagen criteria concerning judicial reforms define goals but they do not provide guidelines on how to craft the institutional framework to reach them. From the analysis of all the regular reports issued by the European Commission for the ten former candidate countries, it follows that the judiciary should be independent and well staffed. Judges must be well trained, well paid, efficient, respected and accessible to people (Coman 2009).

However, despite an almost universal consensus over the importance of judicial independence to democratic rule and its normative value, it is among "the least understood concepts in the field of political science and law" (Larkins 1996, p. 607). Through its regular reports, the European Commission recommended the reduction of the powers of the executives (ministries of justices) over the judiciary in any field related to appointment, promotion or disciplinary proceedings. However, the European Commission remained vague in its recommendations. In the context of enlargement, when the independence of the judiciary became a salient issue in the monitoring of the European Commission, several questions were posed about how to implement it in institutional terms (Coman 2009 , p. 141). How much independence should the judiciary be given in establishing judicial policies and the aspects of a judge's career? The European Commission was hesitant to 
answer the question regarding the degree of independence of the judicial institutions $\mathrm{s}^{3}$ Examining the Commission's approach in evaluating the implementation of this principle, it appeared that judicial reforms were a question of "trust" in the real commitment of political elites in avoiding inference in judicial affairs (Coman 2009) rather than a question of institutional models.

However, to compensate for its inability to explain how the principle of independence should be implemented and why a model is positively evaluated in one country and negatively in another, the European Commission designed the twinning programs as new policy instruments through which civil servants from the old Member States will support the administrative and political elites from the candidate countries in reforming their judicial and administrative structures. If the political conditionality sets the aims to be reached, the twinning programs will become the main "instruments of policing the EU's conditionality” (Papadimitriou \& Phinemmore 2004, p. 624). A careful examination of a series of twinning programs revealed that the application and implementation of the principle of independence of the judiciary produced a variety of institutional models. The twinning programs led to competing conceptions and institutional models on which the candidate countries could base their attempts to improve the guarantees of independence of their judiciaries. Accordingly, in several fields, the absence of an EU model became a reflection of the strength of national traditions across the old EU Member States (Papadimitriou and Phinnemore, 2004, p. 623; Coman 2009).

\section{In search of new mechanisms of compliance}

After the enlargement, Commission officials lamented the difficulty of maintaining pressure on accession states to continue with reforms especially when all the negotiating chapters had been closed (Haughton 2007, p. 240). With the exception to the postponed accessions in Romania and Bulgaria, the 2004 enlargement process showed that "there is little the EU can do to strengthen democratic conditionality" because membership is the highest reward the Union is able to offer (Schimmelfenig, Engert, Knobel 2003, p. 515). Analysing judicial reforms and the rule of law promotion in the new Member States of the EU and the Balkans reveals not only the complexity of the transition to democracy, but also the complexity of this task for the European Union and the European Commission.

Given that the European Commission's responsibility as guardian of the Treaties is to ensure that EU law is upheld, in January 2012 José Manuel Barosso launched legal action against Hungary. Responsible for ensuring that EU law is correctly applied, the Commission has powers of its own to try to bring the infringement to an end. Besides the infringement proceedings, the most serious sanction which the EU can apply to any Member State is the activation of Article 7 of TUE. In the event of a clear threat of a serious breach of the founding principles of the Union "the Council, acting by a qualified majority,

${ }^{3}$ In contrast, the establishment of a comprehensive set of standards of judicial independence has been examined in depth by a variety of international actors, among them the most active being the Venice Commission for Democracy through Law. The institution extensively focused on the meaning of this principle and on the institutional forms it could take at domestic level. 
may decide to suspend certain of the rights deriving from the application of this Treaty to the Member State in question, including the voting rights of the representative of the government of that Member State in the Council”.

Thus, in the letter of formal notice addressed to Hungary: the first stage in the EU's infringement procedure, it was said that the Hungarian legislation conflicts with EU law. Therefore, "changes to the legislation in question, or their immediate suspension, will be able to accommodate the Commission's legal concerns" (European Commission, press release, January 2012). José Manuel Barosso explained the Commission's approach and role in this regard. Following a technical and legal analysis, the concerns related to the reforms undertaken in Hungary have been addressed to the highest political level. But once initiated, the procedure and the arguments advanced by the institution caused comments related to its legal basis. Even if the European Commission argues that the Hungarian democracy is in danger, the infringement procedure does not relate to the separation of power as a fundamental pillar of democracy, but to a breach of the EU legislation on equal treatment and the Hungarian's decision to lower the pension age. Thus, the infringement procedure does not touch on article 2 of the Treaty.

Additionally, in a series of resolutions adopted by the European Parliament, the MEPs deplored that the Commission "limits its own competence to scrutinize Hungary's compliance with the Charter of Fundamental Rights" (European Parliament resolution of 10 March 2011). It is certainly not the first time the MEPs question the ability of the European Commission to play its role as a guardian of the treaties. In front of these critics, José Manuel Barosso acknowledged that beyond the legal aspects, "some concerns have been expressed regarding the quality of democracy". According to him, "these are matters were political judgement is more difficult and, sometimes (...) ideologically polarised" (Parliamentary debates, January 2012).

The first plenary session of the European Parliament in January 2012, initially expected to focus on the election of the new president of the institution, focusing on the incompatibility between the legislation enacted in Hungary and the core principles of the Union. According to Guy Verhofstadt, leader of the ALDE, "the case of Hungary is not just about technical breaches of EU legislation, but a wider concern of gradual but persistent erosion of EU values, as spelled out in Article 2, concerning freedom of expression, of the media and of religion". More critical voices were heard among Green/ EFA group, whose leaders called to launch the infringement procedure under article 7 of the EU Treaty, a measure adopted by the Hungarian Prime Minister and, considered by Rebecca Harms and Daniel Cohn-Bendit a "persistent breach of the basic European values and rights" (Parliamentary debates, January 2012). Similar claims have been expressed by representatives of the Party of European Socialists, who, as members of the Green/EFA group, called for the suspension of the affiliate statute of FIDESz to the European People's Party until democratic standards were re-established in the country. MEPs from these two political groups deplored the "silence" of the representatives of the European People's Party and the absence of reaction vis-à-vis Viktor Orban's policy agenda.

EU pressure acts jointly with other international actors. Where the EU conditionality is weak, the action of the European Commission is supported by the Council of Europe 
and the Venice Commission. While the EU Commission's approach in examining the quality of democracy in Hungary is based on a legal and technical analysis, the European Commission for Democracy through detailed Law expresses opinions on the new Constitution of Hungary and transmitted remarks to the Minister of Foreign Affairs on July 2011 (Venice Commission, opinion no ${ }^{\circ}$ 621/2011). Its recommendations went far beyond the EU Commission's approach used to examine the conformity of the Hungarian rules with the EU's acquis communautaire and treaties. For this reason, in the resolution adopted in February 2012, the EP called on the European Commission to request the opinion of the Venice Commission on the cardinal laws and constitutional provisions to ensure a fully independent judiciary, the right of the Constitutional Court to review legislation and that the National Judicial Authority is governed free from any political influence.

Recent debates illustrate three possible solutions: one solution would be to institutionalise the role the Council of Europe could play in such cases and consequently to accept the limits of the Union, in particular the fact that the "Rule of Law matters are closer to the national legal systems than to EU law" (Vivian Reding, Speech 13/348). Another would be to strengthen the political Union. Between these two extremes of the continuum, the European Commission: supported by some of the Member States, has recently acknowledged the need to find a middle ground between the current "soft power" of the Union in this field and the "nuclear option of article 7" (José Manuel Barroso, State of the Union 2012). While some MEPs expressed their wish to increasingly expand the tasks of the EU in this field and to put in place mechanisms committed to its common values, others argued that some issues, such as those related to the Hungarian reforms, are more appropriately dealt with domestically. In essence, the main dividing line was among those who argued in favour of or against the extension of the EU's political powers, putting forward the tension between internal and external legitimacy (see also Jan Werner Miller 2013).

\section{Conclusions}

This article can be read as an argument to reconsider the outcomes of Europeanisation and the limits of the on-going legal and political integration. Recent developments in Hungarian constitutional and judicial politics offer abundant evidence to question the outcomes of Europeanisation and the mechanisms of compliance through which the EU put Member States to align their politics with European norms and principles. The decision of the Hungarian government to recast the model of the self-administration of the judiciary has been presented as a radical breakthrough. By contrast, at domestic level, the rationale behind the reform has been linked to past failures and to a broader regional debate about the independence of the judiciary.

This article has proved that Europeanisation through conditionality is not sustainable and stands in need of new and stronger mechanisms of compliance. In the search for new mechanisms, one solution would be to institutionalise the role of the Council of Europe in such cases and consequently to accept the limited policy role of the Union. Another 
solution would be to strengthen the political Union and to make use of the existing legal basis concerning EU norms and values. The Hungarian case opened a window of opportunity for redefining the Commission's legitimacy and approach in dealing with sensitive issues such as the independence of the judiciary.

\section{References}

Bodnar, A. \& Bojarski, L. (2011) 'Judicial Independence in Poland', in Anja Seibert-Fohr (ed.), Judicial Independence in Transition, Springer.

Bobek, Michal 2007. 'Iudex Ex Machina : Institutional and Mental Transitions of Central and Eastern European Judiciairies', in Coman Ramona and Jean-Michel De Waele (eds.), Judicial Reforms in Central and Eastern European Countries, Brugge: Vanden Broele.

Brusis, M. 2005. European Union enlargement and the Europeanization of Eastern Europe: research puzzles and policy issues. In: Z. Mansfeldova, V. Sparschuh and A. Wenninger, eds. Patterns of Europeanization in Central and Eastern Europe, Kramer: Hamburg.

Caporaso, J., et al., 2001. Transforming Europe. Europeanization and domestic change. Ithaca and London: Cornell University Press.

Coman, R. And De Waele, J.M. 2007. Judicial reforms in Central and Eastern Europe, from a salient to a salient research topic. In: R. Coman and J.M. De Waele, eds. Judicial Reforms in Central and Eastern European Countries, Buges: Vanden Broele, 1-11.

Coman, R. 2009. Reformer la justice dans un pays post-communiste. Le cas de la Roumanie, Bruxelles : Editions de l'Université.

Dallara, C. 2007. 'Challenges to the democratic judicial reform in Serbia: Legacy of the past, political actors interests and the EU vagueness', in Coman R. \& De Waele J.M. (eds) . Judicial Reforms in Central and Eastern European Countries, Buges: Vanden Broele.

Dallara, C. 2008. 'Serbia: borderline democracy?', in Morlino L. \& Magen A. (eds) Democratization and the European Union. Comparing Central and Eastern European post-communist countries, New York : Routledge.

Domingo, P. 1999. Judicial Independence and Judicial Reforms in Latin America. In: A. Schedler, L. Diamond and M. F. Plattner, eds. The Self-Restraining State. Power and Accountability in New Democracies. Lynne Rienner Publishers: London, 151-177.

Febbrajo, A. 2010. Legal Cultures in Transition: A System-theory Approach. In: A. Febbrajo and W. Sadurski, eds. Central and Eastern Europe After Transition. Towards a New Socio-legal Semantics, Ashgate, 35-73.

Fleck, Z. et al, Opinion on the fundamental law of Hungary, June 2011.

Fleck, Zoltan 2011. 'Judicial Independence in Hungary', in Seibert-Fohr Anja (ed.), Judicial Independence in Transition, Springer.

Friedman, B. 2004. History, Politics and Judicial Independence. In: S. Andras, ed. Judicial Integrity, Martinus Nijhoff Publishers: Leiden, Boston.

Elster, J. 1995. Forces and Mechanisms in the Constitution-Making Process, Duke Law Journal, 45 (2), 364-396.

Epstein, R. A., 2005. 'The paradoxes of enlargement', European Political Research, Vol. 4, pp. 384-394. 
European Parliament, Resolution of 10 March 2011 on Media law in Hungary.

European Parliament, debates, 17 January 2011.

European Commission for Democracy through Law, Opinion on the new Constitution of Hungary, no ${ }^{\circ} 621 / 2011$.

European Commission, Press Release, 7 March 2012.

European Commission, 1998. Regular report from the Commission on Hungary progress towards Accession.

European Commission, 1999. Regular report from the Commission on Hungary progress towards Accession.

European Commission, 2001. Regular report from the Commission on Hungary progress towards Accession, SEC(2001) 1748.

European Commission, 2002. Regular report from the Commission on Hungary progress towards Accession, SEC(2002) 1404.

European Commission, 2003. Comprehensive monitoring report on Hungary's preparations for membership.

EU Observer, MEPs voice 'serious concern' on Hungary's democracy, 16 February 2012.

EU Observer, EU gives Hungary one month to fix laws, 7 March 2012.

Exadaktylos, T. and Radaelli, C. 2009. Research Design in European Studies: The Case of Europeanization, JCMS, 47 (3), 507-530.

Ginsburg, Nuno and Garpupa, Tom 2009. "Guarding the Guardians. Judicial Councils and Judicial Independence", American Journal of Comparative Law, 57, 201-232.

Grabbe, H. 2001. How does Europeanization affect CEE governance? Conditionality, diffusion and diversity. Journal of European Public Policy, 8 (6), 1013-1031.

Grabbe, H. 2002. European Union Conditionality and the Acquis communautaire. International Political Science Review, 23 (3), 249-268.

Goetz, K. 2001. Making sense of post-communist central administration: modernization, Europeanization or Latinization?. Journal of European Public Policy, 8 (6), 1032-1051.

Bankuti, M., Halmai G. Scheppele, K. L. 2012. Hungary's Illiberal Turn. Disabling the Constitution, Journal of Democracy, 23 (3), 138-146.

Hammerslev, O. 2011. "The European Union and the United States in Eastern Europe: two ways of exporting law, expertise and state power", in Y. Dezalay Y. \& B. G. Garth (eds), Bryant Lawyers and the Rule of Law in an Era of Globalization, Routledge.

Haughton, T. 2007. When Does the EU Make a Difference? Conditionality and the Accession Process in Central and Eastern Europe. Political Studies Review, 5 (2), 233-246.

Hill, P., Knill, Ch., 2006. 'It's the Bureaucracy Stupid. The Implementation of the Acquis Communautaire in the EU Candidate Countries, 1999-2003', European Union Politics, 7,4 .

Hughes, J., Sasse, G., Gordon, C. 2004a. Conditionality and Compliance in the EU's Eastward Enlargement: Regional Policy and the Reform of Sub-national Government. Journal of Common Market Studies, 42 (3), 523-551.

Hughes, J., Sasse, G., Gordon, C. 2004b. Europeanization and regionalization in the EU's enlargement to Central and Eastern Europe: the myth of conditionality, Basingstoke: Palgrave. 
Juncos, A. 2011. Europeanization by Decree? The case of Police Reform in Bosnia. JCMS, 49 (2), 367-389.

Kotzian, P., Knodt, M. and Urdze, S., Instruments of the EU's external democracy promotion, JCMS, 49 (5), 923-1152.

Kochenov, D. 2004. Behind the Copenhagen façade. The meaning and the structure of the Copenhagen Political Criterion of democracy and the rule of law. European Integration online Papers, 8 (10), 1-36.

Kosar, D. 2010. 'Judicial Accountability in the (Post)Transitional Context: A Story of the Czech Republic', in Czarnota A. \& Parmentier S. (eds) (2010).

Ladrech, R. 2010. Europeanization and National Politics. Basingstoke: Palgrave Macmillan.

Larkins, K. 1996. Judicial Independence and Democratization: A Theoretical and Conceptual Analysis. The American Journal of Comparative Law, 44 (4), 605-626.

Magalhaes, P. C. 1999. The Politics of Judicial Reform in Eastern Europe. Comparative Politics, 32 (1), 43-62.

Melone, A. P. 1996. The Struggle for Judicial Independence and the Transition toward Democracy in Bulgaria. Communist and Post-Communist Studies, 29 (2), 231-243.

Muller, J. W. 2013. Defending Democracy within the EU, Journal of Democracy, 24(2), 138-149.

O’Dwyer, C.2006.Reforming RegionalGovernancein East CentralEurope:Europeanization or Domestic Politics as usual. East European Politics and Societies, 20(2), 219-253.

Open Society Institute 2001. Monitoring the EU Accession Process: Judicial Independence, Budapest.

Parau, C. 2011. “The Drive for Judicial Supremacy”, in Anja Seibert-Fohr (ed.), Judicial Independence in Transition, Springer.

Papadimitriou, D. and Phinnemore, D. 2004. Europeanization, Conditionality and Domestic Change: The Twinning Exercice and Administrative Reform in Romania. Journal of Common Market Studies, 42 (3), 619-639.

Pederzoli, P. And Piana, D. 2010. The Governance of the Judicial System in Europe. In: R. Coman and C. Dallara, eds. Handbook on Judicial Politics, Iasi: Institutul European, 89-121.

Piana, D. 2010. Judicial Accountabilities in New Europe. From Rule of Law to Quality of Justice. Ashgate.

Přibáň, J. 2004. Reconstituting Paradise Lost: Temporality, Civility, and Ethnicity in PostCommunistConstitution-Making. Law \& Society Review, 38 (3), 407-432.

Přibáň, J. 2010. Constituting the Heterarchy of European Constitutionalism in the EU's New Member States. In: In: A. Febbrajo and W. Sadurski, eds. Central and Eastern Europe After Transition. Towards a New Socio-legal Semantics, Ashgate, 13-35.

Pridham, G. 2006. Assessing Democratic Consolidation in Central and Eastern Europe: The European Dimension. Acta Politica, 41, 342-369.

Pogany, I. 1993. Constitutional Reform in Central and Eastern Europe: Hungary's Transition to Democracy. The International and Comparative Law Quarterly, 42 (2), 332-355.

Ravinet, P. 2011. ,La coordination européenne «à la bolognaise»' Revue française de science politique, 61, 1 . 
Richardson, J. T. 2006. Religion, Constitutional Courts, and Democracy in Former Communist Countries. Annals of the American Academy of Political and Social Science, 603, 129-138.

Saurugger, S. (2012) "Beyond Non-Compliance with Legal Norms", in Exadaktylos, T. and Radaelli, C. M. (eds). Research Design in European Studies. Establishing Causality in Europeanization, New York: Palgrave.

Sajo, A. 1995. Reading the Invisible Constitution: Judicial Review in Hungary. Oxford Journal of Legal Studies, 15 (2), 253-267.

Sadurski, W. 2008. Solange, chapter 3': Constitutional Courts in Central EuropeDemocracy European Union. European Law Journal, 14 (1), 1-35.

Schedler, A. 1999. Retraining the State: Conflicts and Agents of Accountabiity. In: A. Schedler, L. Diamond and M. F. Plattner, eds. The Self-Restraining State. Power and Accountability in New Democracies. Lynne Rienner Publishers: London, 333-351.

Scheppele, K. L. 2006. Guardians of the Constitution: Constitutional Court Presidents and the Struggle for the Ruleof Law in Post-Soviet Europe. University of Pennsylvania Law Review, 154 (6), 1757-1851.

Schimmelfennig, F., Engert, S. and Knobel, H. 2003. Costs, Commitment and COmpliance: The Impact of EU Democratic Conditionality on Latvia, Slovakia and Turkey. Journal of Common Market Studies, 41 (3), 495-518.

Schimmelfennig, F. and Sedelmeier, U. 2004. Governance by conditionality : EU rule transfer to the candidate countries of Central and Eastern Europe. Journal of European Public Policy, 11 (4), 661-679.

Schönfelder, Bruno (2005). "Judicial Independence in Bulgaria: A Tale of Splendour and Misery”, Europe-Asia Studies, 57: 1, 61-92.

Schwartz, H. 1999. Surprising Success: The New Eastern European Constitutional Courts. In: A. Schedler, L. Diamond and M. F. Plattner, eds. The Self-Restraining State. Power and Accountability in New Democracies. Lynne Rienner Publishers: London, 195-217.

Seleny, A. 1999. Old Political Rationalities and New Democracies: Compromise and Confrontation in Hungary and Poland. World Politics, 51, 484-519.

Sticka, M. (2007) 'Top-down control slows Czech judicial reform, despite EU impetus' in Transparency International

Spinner, M. 2005. Aspects of democracy. Democratic consolidation in Eastern Europe: old wine in new bottles?. European Political Science, 4, 443-453.

Uitz, R. 2010. Hungary : high hopes revisited. In : L. Morlino and W. Sadurski, (eds) Democratization and the European Union. Comparing Central and Eastern European post-communist countries, New York : Routledge, 45-71.

Wuller, J.W. 2013. Defending Democracy within the EU, Journal of Democracy, 24 (2), 2013, 138-149.

Wolczuk, K. 2007. Constitutional Politics. In: S. White, J. Batt and Paul G. Lewis, eds. Developments in Central and East European Politics, Palgrave. 